\title{
Financial Analysts' Understanding of Accounting Matching and Their Earnings Forecast Accuracy
}

\author{
Liya Hou \\ St. Cloud State University
}

\begin{abstract}
This study examines the relation between analysts' understanding of accounting matching and their earnings forecast accuracy. By creating an innovative measure of analysts' understanding of accounting matching, I find that financial analysts who better understand firms' accounting matching produce more accurate earnings forecasts, and their earnings forecasts are more accurate than the earnings forecasts based on the historical expense-revenue relation. The findings suggest that better understanding of firms' accounting matching helps financial analysts to determine the components of firms' accounting numbers, facilitates analysts forecast decision process and reflects analysts'valuable insights into the properties of firms' earnings and their abilities to produce earnings forecasts with greater accuracy, and that since analysts use various information as input to forecast earnings, their forecasts are more accurate than the earnings forecasts that are solely based on the historical expense-revenue relation.
\end{abstract}

Keywords: revenue-expense matching, financial analyst forecast accuracy, financial analysts' understanding of accounting matching

\section{INTRODUCTION}

The financial analyst literature has so far examined various factors that affect financial analyst forecast accuracy. For instance, prior studies find that CSR (corporate social responsibility reports)-initiating firms with superior CSR performance are associated with lower financial analyst forecast error (Dhaliwal et al., 2011), that private information from lending activities improves the forecast accuracy of bank-affiliated analysts (Chen and Martin, 2011) and that the condensed equity method disclosures increase information asymmetry, increasing analysts' forecast errors and forecast dispersion (Lee et al., 2013). However, the prior research has not investigated the relation between financial analyst earnings forecast accuracy and their understanding of firms' accounting matching, defined as the recognition of expenses attributable to recognized revenues. This study explores the linkage between financial analysts' understanding of accounting matching and their earnings forecast accuracy. Specifically, I examine whether financial analysts who better understand firms' accounting matching produce more accurate earnings forecasts and whether analyst earnings forecasts are better than the earnings forecasts based on the historical expenserevenue relation.

To investigate my research question, I create an innovative measure of analysts' understanding of firms' accounting matching in two ways: first, I calculate the absolute value of the difference $\left(A B S \_R 2\right)$ between the adjusted-R-squared (from the regression of firms' actual expense on firms' actual revenue over the eight continuous quarters) and the adjusted-R-squared (from the regression of financial analysts' expenses 
forecast on financial analysts' revenues forecast over the eight continuous quarters); second, I calculate the absolute value of the difference ( $A B S \_$Coef $)$between the coefficient on actual revenue (from the regression of firms' actual expense on firms' actual revenue over the eight continuous quarters) and the coefficient on revenue forecast (from the regression of financial analysts' expenses forecast on financial analysts' revenues forecast over the eight continuous quarters). Next, I regress financial analysts' earnings forecast error on $A B S \_R 2$ and $A B S \_$Coef separately and include a list of control variables that affect financial analysts' earnings forecast accuracy, such as firms' characteristics control variables and financial analysts' characteristics control variables. The empirical results support my prediction that financial analysts who have poor understandings of firms' accounting matching produce earnings forecasts with larger forecast errors. In another word, financial analysts who better understand firms' accounting matching can produce more accurate earnings forecasts. Furthermore, I find that analyst earnings forecasts are more accurate than the earnings forecasts based on the historical expense-revenue relation.

My paper is the first study that investigates the relation between financial analysts' understanding of accounting matching and their earnings forecast accuracy by using an innovative measure. This study contributes to both of the financial analyst literature and accounting matching literature by showing that better understanding of firms' accounting matching helps financial analysts to determine the components of firms' accounting numbers and thus produce more accurate earnings forecasts.

My paper is structured as follows: Section 2 provides a general background on accounting matching, financial analyst forecast, and my hypotheses; Section 3 discusses the research design; Section 4 presents the empirical results, and Section 5 concludes.

\section{LITERATURE REVIEW AND HYPOTHESES}

\section{Literature Review of Accounting Matching}

One of the fundamental principles in accounting is matching of expenses to revenues. The matching principle requires a firm's expenses to be recognized in the same period in which revenues are earned. Dichev and Tang (2008) investigate the effects of poor matching on the properties of accounting earnings over the last 40 years, and they measure matching by the contemporaneous relation between revenues and expenses. They find an economically substantial decline in matching, increased earnings volatility, declining earnings persistence and increased negative autocorrelation in earnings changes, suggesting that accounting matching has become worse over time.

Consistent with Dichev and Tang (2008), Donelson, Jennings, and McInnis (2011) also find a decline in the contemporaneous revenues and expenses relationship. Building upon Dichev and Tang (2008), they identify which expense line items are responsible for the decline in matching and find that the decline is primarily driven by a low correlation between revenues and special items and an increase in the incidence of large special items over time.

Although prior studies interpret the decline in matching as a decrease in earnings quality, they disagree on whether it results from changes in economic activity or changes in specific accounting standards. Donelson et al. (2011) therefore investigate the driver of the increasing incidence of special items and find that it is likely due to changes in economic activities, such as increasing competitive pressure.

Srivastava (2014) also examines the source of the changes in earnings properties and finds that each new cohort of listed firms exhibits lower earnings quality than its predecessors, mainly because of higher intangible intensity, suggesting that the trend of decline in earnings quality is due more to changes in the sample of firms than to changes in generally accepted accounting principles (GAAP) or in the earnings quality of previously listed firms. Srivastava (2014) also provides evidence that a decline in matching is associated with increasing R\&D expenses and higher period costs relative to variable costs in U.S. industries.

Rather than deriving revenues from expenses by measuring revenue as a function of expense as in Dichev and Tang (2008), Prakash and Sinha (2013) estimate accounting matching in the context of deferred revenue by using profit margins. They argue that if firms defer the recognition of revenue without deferring the recognition of associated expenses, the consequent mismatch of revenue and expenses affects reported 
margins in current and in future periods. Based on the passage of Staff Accounting Bulletin No. 101 in 2000 that resulted in increased recognition of deferred revenues, they find that changes in the current deferred revenue liability have a significant impact on current and year-ahead profit margins and that such changes make current profit margins poor predictors of future margins.

In order to better understanding the reasons for the decline in matching in the United States, He and Shan (2015) use a sample of 42 countries to examine the trend in matching between revenues and expenses and its determinants. They find that the decline in matching is not unique to the United States but occur around the world in the past two decades. By using cross-country differences in several institutional factors, they find that matching is weaker in counties with a wider use of accrual accounting, a larger number of firms reporting large special items, lower economic growth, more R\&D activities, large service sectors and stronger investor protections.

Bushman, Lerman, and Zhang (2016) employ the adjusted R square from the annual cross-sectional regressions of revenues on lead, lag, and contemporaneous expense as a more direct measure of the random error component of expense recognition to measure matching. They find that temporal changes in the matching between revenues and expenses, and the growth of intangible-intensive industries play only a limited role in explaining the dramatic decline in the correlation between accruals and cash flows.

\section{Hypotheses}

The decision process through which financial analysts forecast earnings has been known as a "blackbox" (Bradshaw, 2009, 2011), and it is interesting to use a fundamental principle in accounting, that is accounting matching, to explore the factors that affect financial analysts forecast decision process. Specially, good matching of revenues to expenses can appropriately measure earnings, whereas poor matching can lead to an underestimation or overestimation of earnings and reduce earnings' usefulness in measuring a corporate performance (He and Shan, 2016).

Since the matching of expenses to revenues has great impact on the determination of earnings, I expect that accounting matching plays an important role in facilitating financial analysts forecast decision process, and that better understanding of firms' accounting matching reflect financial analysts' valuable insights into the properties of firms' accounting earnings and their abilities to produce earnings forecasts with greater accuracy. Besides, since analysts use various information as input to forecast earnings, their forecasts should be more accurate than the earnings forecasts that are solely based on the historical expenserevenue relation.

Intuitively, it is more difficult for financial analysts to predict a firm's accounting numbers if its matching is poor, as poor matching adds noise to earnings by spreading out costs.

Based on the above discussions, I propose the following hypotheses, in alternative form:

H1: Financial analysts who better understand firms' accounting matching produce more accurate earnings forecasts.

H2: Financial analyst earnings forecasts are more accurate than the earnings forecasts based on the historical expense-revenue relation.

\section{RESEARCH DESIGN}

\section{Measure of Financial Analysts' Earnings Forecast Error}

Financial analysts' earnings forecast error, $E 1_{\text {analyst }, q}$, is measured as the absolute value of the difference between the firms' actual earnings, $N E T_{F i r m, q}$, and financial analysts' earnings forecast, $N E T_{\text {analyst, } q}$ (NET from IBES), deflated by the market value of equity, $M V_{F i r m, q}$, for quarter $q$.

$E 1_{\text {analyst }, q}=\frac{\left|N E T_{\text {Firm }, q}-N E T_{\text {analyst }, q}\right|}{M V_{\text {Firm }, q}}$ 


\section{Measure of Financial Analysts' Understanding of Firms' Accounting Matching}

I conduct the following procedures to measure financial analysts' understanding of firms' accounting matching captured by their forecast matching-errors.

First, I regress firms' actual expense $\left(E X P_{\text {Firm }, q-t}\right.$ from IBES) on firms' actual revenue $\left(S A L_{F i r m, q-t}\right.$ from IBES) over the eight continuous quarters (i.e., $t=1,2,3, \ldots 8$ ) shown in Figure 1 as follows:

$$
E X P_{\text {Firm }, q-t}=a_{1}+a_{2} S A L_{\text {Firm }, q-t}+v_{\text {Firm }, q-t}
$$

\section{THE TIMELINE FOR RELATED ACCOUNTING MATCHING MEASURES}

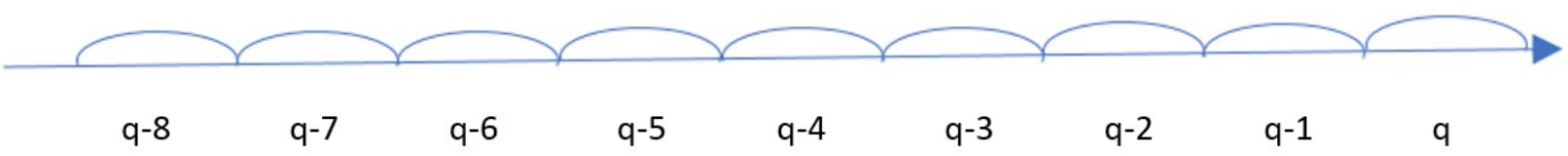

Second, I calculate the adjusted-R-squared, Actual_R2 Firm, $q-1$, and the coefficient on revenue $S A L_{F i r m, q-t}$, $a_{2}$ (Actual_Coef Firm, $\left.q-1\right)$, from the above model (2).

Third, I regress financial analysts' expenses forecast ( $E X P_{\text {Analyst }, q-t}$ from IBES) on their revenues forecast $\left(S A L_{\text {Analyst },-t}\right.$ from IBES) over the eight continuous quarters (i.e., $t=1,2,3, \ldots 8$ ) as follows:

$E X P_{\text {Analyst }, q-t}=b_{1}+b_{2} S A L_{\text {Analyst }, q-t}+u_{\text {Analyst }, q-t}$

Fourth, I calculate the adjusted-R-squared, $R 2_{\text {analyst }, q-1}$, and the coefficient on revenue $S A L_{\text {Analyst }, q-\mathrm{t}}, b_{2}$, from the above model (3).

Finally, I measure financial analysts' understanding of firms' accounting matching in two ways as follows:

$A B S_{-} R 2_{\text {Analyst }, q-1}=\mid$ Actual_R2 $2_{\text {Firm }, q-1}-R 2_{\text {analyst }, q-1} \mid$

where $A B S_{-} R 2_{\text {Analyst, } q-1}$ is the absolute value of the difference between the adjusted-R-squared, Actual_R2 Firm, $q-1$ and the adjusted-R-squared, $R 2_{\text {analyst }, q-1}$.

$A B S_{-}$Coef $f_{\text {Analyst }, q-1}=\left|a_{2}-b_{2}\right|$

where ABS_Coef Analyst, $q-1$ is the absolute value of the difference between the coefficient $a_{2}$ (Actual_Coef $\left.\overline{F i r m}, q-1_{1}\right)$ and the coefficient $b_{2}$.

\section{Measure of Earnings Forecasts based on the Historical Expense-revenue Relation}

I conduct the following procedures to measure earnings forecasts based on the historical expenserevenue relation.

First, I regress firms' actual expense $\left(E X P_{\text {Firm }, q-t}\right.$ from IBES) on firms' actual revenue $\left(S A L_{F i r m, q-t}\right.$ from IBES) over the eight continuous quarters (i.e., $t=1,2,3, \ldots 8$ ) and obtain the intercept $a_{1}$ and the coefficient on revenue $S A L_{\text {Firm }, q-\mathrm{t}}, a_{2}$, from the above model (2).

Second, I calculate the analysts' expense forecast based on the historical expense-revenue relation, $\operatorname{Exp}_{\text {estımated, }}$, estimated as $a_{1}$ plus $a_{2} \times$ Analysts' revenue forecast $\left(S A L_{\text {Analyst }, q}\right)$ as follows:

$\operatorname{Exp}_{\text {estlmated }, q}=a_{1}+a_{2} \times S A L_{\text {Analyst }, q}$ 
Third, I calculate the earnings forecasts based on the historical expense-revenue relation, $N E T_{\text {estımated, } q}$, estimated as the difference between the analysts' revenue forecast $\left(S A L_{\text {Analyst, } q}\right)$ and the estimated expense forecast (Exp $\widehat{\text { estimated,q }})$.

$N E T_{\text {estımated }, q}=S A L_{\text {Analyst }, q}-$ Exp $_{\text {estımated }, q}$

Finally, I calculate the absolute value of the difference between the firms' actual earnings, $N E T_{F i r m, q}$, and the estimated expense forecast ( $\operatorname{Exp}_{\text {estımated, } q}$ ), deflated by the market value of equity, $M V_{F i r m, q}$, for quarter $q$.

$E 2_{\text {estlmated }, q}=\frac{\mid N E T_{\text {Firm }, q}-N E T_{\text {estumated }, q \mid}}{M V_{\text {Firm }, q}}$

\section{Tests of Hypotheses}

I test Hypothesis 1 in two ways. First, I regress financial analysts' earnings forecast error, $E 1_{\text {analyst }, q}$, on $A B S \_R 2_{\text {Analyst }, q-1}$ in model (9) as follows:

$E 1_{\text {analyst }, q}=\beta_{1} A B S_{-} R 2_{\text {Analyst }, q-1}+\beta_{2}$ Actual_R2 Firm,$q-1+$ Firm Characteristics Controls

+ Analyst Characteristics Controls + Analyst Fixed Effect

+ Year Fixed Effect $+v_{q}$

Second, I regress financial analysts' earnings forecast error, $E 1_{\text {analyst }, q}$, on $A B S_{-}$Coef $f_{\text {Analyst }, q-1}$ in model (10) as follows:

$E 1_{\text {analyst }, q}=\lambda_{1}$ ABS_Coef Analyst,$q-1_{1}+\lambda_{2}$ Actual_Coef Firm,$q-1_{1}+$ Firm Characteristics Controls

+ Analyst Characteristics Controls + Analyst Fixed Effect

+ Year Fixed Effect $+v_{q}$

In both models (9) and (10), I include the control variables (discuss in detail later) that affect financial analysts' earnings forecast accuracy, such as firm characteristics control variables (size, book-to market ratio, leverage, profit margin, litigation risk, high-tech firm indicator, R\&D expense, loss indicator, and PPE) and financial analysts characteristics control variables (financial analysts' experience, and financial analysts' firm-specific experience). Standard errors are two-way clustered by firm and year.

If the coefficient $\beta_{1}$ on $A B S_{-} R 2_{\text {Analyst }, q-1}$, or the coefficient $\lambda_{1}$ on $A B S_{-}$Coef $f_{\text {Analyst }, q-1}$, is positive and statistically significant, then it suggests that financial analysts who have poor understandings of firms' accounting matching produce earnings forecasts with larger forecast errors. In another word, financial analysts who better understand firms' accounting matching produce more accurate earnings forecasts.

To test Hypothesis 2, I compare the analysts' earnings forecast error, $E 1_{\text {analyst }, q}$ with the estimated earnings forecast error $E 2_{\text {estımated, } q}$. If $E 1_{\text {analyst, } q}$ is significantly smaller than $E 2_{\text {estımated, } q}$, then it suggests that analyst earnings forecasts are better than the earnings forecasts based on the historical expense-revenue relation.

\section{Control Variables}

I include a set of control variables, such as firm characteristics control variables and financial analyst characteristics control variables, that affect firms' accounting matching and thus financial analysts' earnings forecast accuracy.

Size

Based on Dichev and Tang (2008), poor matching can be caused by managerial discretion and aggressive accounting, whereby current revenues are recognized in the current period, but current expenses 
are recognized in the following period by delaying recognition of current expenses. Core et al. (2008) find a large negative correlation between size and accrual quality (AQ), where lower AQ is considered to be higher accounting quality, so large firms usually have better accrual quality. As high AQ can be a red flag that management uses aggressive accounting to overstate earnings, I expect that larger firms have less managerial discretion and use less aggressive accounting, and thus have better accounting matching. Besides, Srivastava (2011) finds similar evidence that in the United States, large firms have larger matching coefficients than smaller and younger firms.

Size is measured as nature log of MVQ, where MVQ is measured as market value of equity (PRCCQ $\times$ CSHOQ).

\section{Book-to-Market Ratio}

Firms with low book-to-market ratio are usually growth firms. LaFond and Watts (2008) argue that market-to-book ratio (MB) reflects growth options and find that firms with high MB have high information asymmetries, which implies high managerial discretion and poor matching. Therefore, I expect that firms with high BTM have better accounting matching.

Book-to-Market Ratio is measured as the ratio of book value equity (CEQQ) to market value equity $(\mathrm{PRCCQ} \times \mathrm{CSHOQ})$.

\section{Leverage}

Leverage proxies for the firm's relative amount of non-growth option investments. Since only such investments generate debt capacity, leverage will also measure the debt contracting demand for conservatism (LaFond and Watts, 2008). In essence, conservatism can be viewed as a form of "poor matching", where the expenses precede the associated revenues (Dichev and Tang, 2008). Therefore, I expect that firms with higher leverage will have lower accounting matching.

Leverage is measured as the ratio of total debt, both long-term and short-term, to total assets ((DLTTQ+DLCQ)/ATQ).

\section{Profit Margin}

Jimmy Lee (2011) conjectures that profit margin is a proxy for a firm's performance, and a firm with poor performance is also more likely to recognize expense ahead of the associated revenue such as taking a big bath, which results in a poor accounting matching (Dichev and Tang, 2008). Therefore, I expect that firms with higher profit margin have better accounting matching.

Profit margin is measured as the ratio of earnings before extraordinary items to net revenues (IBQ/SALEQ).

\section{Litigation}

Managers in firms with more litigation risks and investor monitoring may have less discretion in recognizing revenues and expenses (He and Shan, 2016). I expect that firms that face high litigation risks have more monitoring, and therefore have less managerial discretion and better accounting matching. Following Johnson et al. (2001), litigation risk is measured by the first principal component of five market variables, which are equity beta, share turnover, market value, return skewness, and annual return.

\section{High-Tech Firms and R\&D Expense}

Dichev and Tang (2008) argue that changes in the real economy toward more R\&D-type activities imply a temporal decline in accounting matching success, and Srivastava (2014) provides evidence that a decline in accounting matching is associated with increasing R\&D expenses. Since high-tech firms usually have more R\&D spending than firms in other industries and these technology firms usually immediately expense investment expenditures such as R\&D and advertising (Prakash and Sinha, 2013), resulting in mismatching, I expect that high-tech firms and firms have high R\&D expense have lower accounting matching. 
High-tech firm is an indicator variable that is set equal to 1 if the firm belongs to any of the following four-digit SIC industry codes: 2833-2836, 3570-3577, 3600-3674, 7371-7379, or 8731-8734, and firm's $\mathrm{R} \& \mathrm{D}$ expense is measured as Compustat data XRDQ/SALEQ.

\section{Loss Indicator}

Donelson et al. (2011) find that the decline in accounting matching is attributable primarily to a steady increase in the frequency of large special items. Since loss firms are more likely to be affected by economic recessions and recognize large amount of special items losses, I expect that loss firms are more likely to have lower accounting matching between revenues and expenses.

Loss is an indicator variable that is set equal to 1 if the firm's earnings is negative (IBQ $<0)$.

$P P \& E$

Srivastava (2014) provides evidence that a decline in accounting matching is associated with higher period costs relative to variable costs in U.S. industries. Since firms with high PP\&E usually have more period costs such as depreciation expense relative to variable costs, I expect that high PP\&E firms are more likely to have lower accounting matching between revenues and expenses.

Firm's Property, Plant and Equipment is measured as Compustat data PPEGTQ/ATQ.

\section{Financial Analysts' Experience}

Financial analysts' experience is measured in two ways: (i) Financial analyst's experience, calculated as the difference between the observation year and the first year that the financial analyst is shown on IBES, (ii) Financial analyst's firm-specific experience, calculated as the difference between the observation year and the first year that the financial analyst is shown for a specific firm on IBES. Financial analysts who have more experience should be able to forecast earnings with greater accuracy.

\section{EMPIRICAL RESULTS}

Table 1 displays the sample selection procedure. I obtain accounting data from Standard \& Poor's Compustat database, and obtain the financial analyst earnings forecasts data, financial analyst revenues forecasts data, and firms' actual value data from I/B/E/S Detail File with Actuals from 2003 to 2015. I discard observations with missing values, and with financial analyst forecasts made after the earnings announcements. I then keep the latest financial analyst forecasts made before the earnings announcements. I merger financial analyst revenue forecasts with financial analyst earnings forecasts, and merger financial analyst forecasts database with Compustat database. Finally, I discard observations with insufficient data to compute the regressions. The final sample consists of 28,623 firm-quarter observations.

Table 2 shows the description of the key variables used in the empirical tests. Table 3 Panel A reports summary statistics for the sample, and Panel B shows pairwise correlations.

\section{TABLE 1 SAMPLE CONSTRUCTION}

\begin{tabular}{ll}
\hline Selection criteria & $\begin{array}{l}\text { Number of } \\
\text { observations }\end{array}$ \\
\hline All IBES quarterly database in fiscal years 2003-2015 & $2,845,355$ \\
Discard observations with missing values & $2,805,473$ \\
Discard observations with analyst forecasts made after the earnings announcements & $2,791,575$ \\
Keep the latest financial analyst forecasts made before the earnings announcements & $2,030,863$ \\
Merger financial analyst revenue forecasts with financial analyst earnings forecasts & 872,092 \\
Merger financial analyst forecasts database with Compustat database & 594,262 \\
Discard observations with insufficient data to compute the regression & 28,623 \\
\hline
\end{tabular}


TABLE 2

DESCRIPTION OF KEY VARIABLES

\begin{tabular}{|c|c|}
\hline Variable & Definition \\
\hline Size & $\begin{array}{l}\text { Nature log of MVQ, where MVQ is measured as market value of equity (PRCCQ } \times \\
\text { CSHOQ) }\end{array}$ \\
\hline BTM & The ratio of book value equity $(\mathrm{CEQQ})$ to market value equity $(\mathrm{PRCCQ} \times \mathrm{CSHOQ})$ \\
\hline LEV & $\begin{array}{l}\text { Leverage, measured as the ratio of total debt, both long-term and short-term, to total } \\
\text { assets ((DLTTQ+DLCQ)/ATQ) }\end{array}$ \\
\hline Margin & $\begin{array}{l}\text { Profit margin, measured as the ratio of earnings before extraordinary items to net } \\
\text { revenues (IBQ/SALEQ) }\end{array}$ \\
\hline Litigation & $\begin{array}{l}\text { Litigation risk is measured by the first principal component of five market variables, } \\
\text { which are equity beta, share turnover, market value, return skewness, and annual } \\
\text { return (Johnson et al. 2001) }\end{array}$ \\
\hline HITECH & $\begin{array}{l}\text { High-tech firm, an indicator variable that is set equal to } 1 \text { if the firm belongs to any } \\
\text { of the following four-digit SIC industry codes: } 2833-2836,3570-3577,3600- \\
3674,7371-7379 \text {, or } 8731-8734\end{array}$ \\
\hline $\mathrm{R} \& \mathrm{D}$ & Firm’s R\&D expense (XRDQ/SALEQ) \\
\hline Loss & An indicator variable that is set equal to 1 if the firm's earnings is negative $(\mathrm{IBQ}<0)$ \\
\hline PPE & Firm's Property, Plant and Equipment (PPEGTQ/ATQ) \\
\hline Alyst_EXP & $\begin{array}{l}\text { Financial analyst's experience, calculated as the difference between the observation } \\
\text { year and the first year that the financial analyst is shown on IBES }\end{array}$ \\
\hline Alyst_FEXP & $\begin{array}{l}\text { Financial analyst's firm-specific experience, calculated as the difference between } \\
\text { the observation year and the first year that the financial analyst is shown for a } \\
\text { specific firm on IBES }\end{array}$ \\
\hline ABS_R2 & 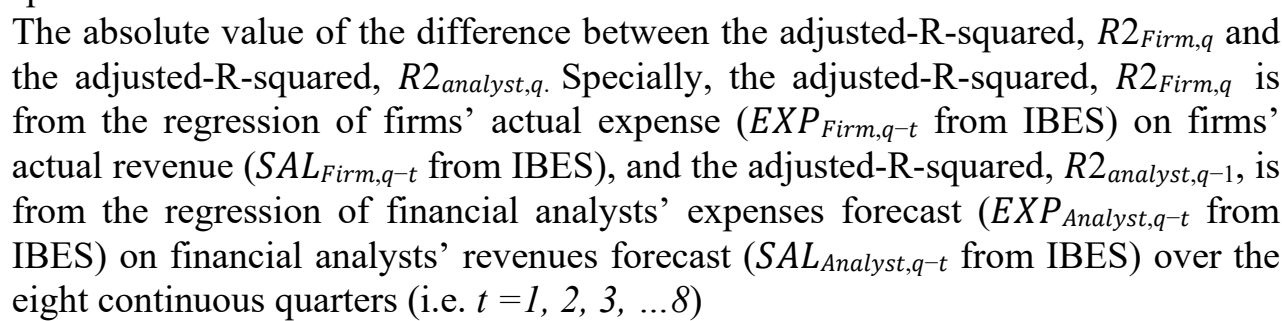 \\
\hline Actual_R2 & $\begin{array}{l}\text { The adjusted-R-squared, } R 2_{\text {Firm } q} \text { is from the regression of firms' actual expense } \\
\left(E X P_{\text {Firm },-t} \text { from IBES) on firms' actual revenue }\left(S A L_{\text {Firm }, q-t} \text { from IBES) }\right.\right.\end{array}$ \\
\hline ABS_Coef & $\begin{array}{l}\text { The absolute value of the difference between the coefficients from the regressions } \\
\text { based on firms' actual value and the coefficients from the regressions based on } \\
\text { financial analysts' forecast value for the previous eight continuous quarters }\end{array}$ \\
\hline Actual_Coef & $\begin{array}{l}\text { The coefficient from the regression based on firms' actual value, obtained by } \\
\text { regressing firms' actual value of expense on revenue for eight continuous quarters }\end{array}$ \\
\hline$E 1$ & $\begin{array}{l}\text { Financial analysts' earnings forecast error, measured as the absolute value of the } \\
\text { difference between the firms' actual earnings, NETFirm, } q \text {, and financial analysts' } \\
\text { earnings forecast, NETanalyst, } q \text {. (NET from IBES), deflated by the market value } \\
\text { of equity, MVFirm, } q \text {, for quarter } q \text {. }\end{array}$ \\
\hline E2 & $\begin{array}{l}\text { The absolute value of the difference between the firms' actual earnings, } N E T_{F i r m, q} \text {, } \\
\text { and the estimated expense forecast }\left(\operatorname{Exp}_{\text {estımated, },}\right) \text {, deflated by the market value } \\
\text { of equity, } M V_{\text {Firm, } q} \text {, for quarter } q \text {. }\end{array}$ \\
\hline
\end{tabular}


TABLE 3

DESCRIPTIVE STATISTICS

Panel A: Summary Statistics

\begin{tabular}{lcccccc}
\hline & $\mathrm{N}$ & Mean & STD & Q1 & Median & Q3 \\
\hline Size & 28623 & 8.847 & 1.810 & 7.607 & 8.827 & 10.127 \\
BTM & 28623 & 0.386 & 0.291 & 0.202 & 0.321 & 0.489 \\
LEV & 28623 & 0.214 & 0.202 & 0.043 & 0.178 & 0.306 \\
Margin & 28623 & 0.063 & 0.175 & 0.023 & 0.072 & 0.144 \\
Litigation & 28623 & 0.568 & 0.495 & 0.000 & 1.000 & 1.000 \\
HITECH & 28623 & 0.409 & 0.492 & 0.000 & 0.000 & 1.000 \\
R\&D & 28623 & 0.095 & 0.106 & 0.000 & 0.061 & 0.154 \\
Loss & 28623 & 0.171 & 0.377 & 0.000 & 0.000 & 0.000 \\
PPE & 28623 & 0.478 & 0.329 & 0.205 & 0.385 & 0.699 \\
Alyst_EXP & 28623 & 12.444 & 6.893 & 7.000 & 11.000 & 17.000 \\
Alyst_FEXP & 28623 & 6.390 & 4.229 & 3.000 & 5.000 & 8.000 \\
ABS_R2 & 28623 & 0.067 & 0.132 & 0.002 & 0.013 & 0.059 \\
Actual_R2 & 28623 & 0.862 & 0.239 & 0.868 & 0.967 & 0.993 \\
ABS_Coef & 28623 & 0.072 & 0.123 & 0.011 & 0.031 & 0.078 \\
Actual_Coef & 28623 & 0.758 & 0.215 & 0.656 & 0.787 & 0.897 \\
E1 & 28623 & 0.003 & 0.006 & 0.000 & 0.001 & 0.003 \\
E2 & 28623 & 0.006 & 0.022 & 0.001 & 0.002 & 0.005 \\
\hline
\end{tabular}




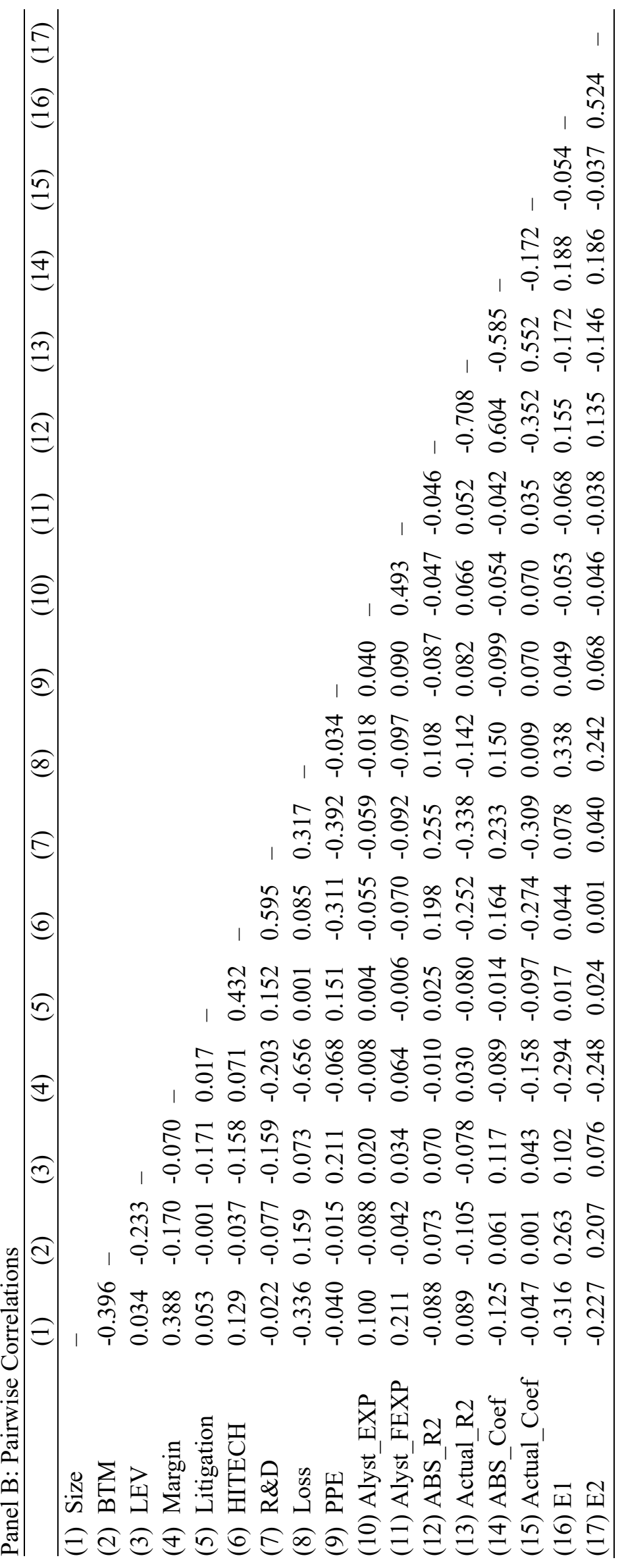


Table 4 Panel A shows the summary statistics of the adjusted-R-squared, $R 2_{\text {Firm }, q}$ from the regression of firms' actual expense ( $E X P_{\text {Firm }, q-t}$ from IBES) on firms' actual revenue ( $S A L_{\text {Firm }, q-t}$ from IBES) over the eight continuous quarters in model (2) from 2004 to 2015. Panel B shows the summary statistics of the adjusted-R-squared $R 2_{\text {analyst }, q-1}$ from the regression of financial analysts' expenses forecast $\left(E X P_{\text {Analyst }, q-t}\right.$ from IBES) on their revenues forecast ( $S A L_{\text {Analyst }, q-t}$ from IBES) over the eight continuous quarters in model (3) from 2004 to 2015. Consistent with prior literature (i.e., Dichev and Tang 2008; Srivastava 2011), I find a trend of decline in accounting matching based on these two measures.

TABLE 4

THE TRENDS IN ACCOUNTING MATCHING

Panel A: The adjusted-R-squared from the regression based on firms' actual values.

\begin{tabular}{llllll}
\hline Period & Mean & STD & Q1 & Median & Q3 \\
\hline $2004-2005$ & 0.915 & 0.182 & 0.931 & 0.982 & 0.995 \\
$2006-2007$ & 0.899 & 0.217 & 0.926 & 0.983 & 0.996 \\
$2008-2009$ & 0.887 & 0.230 & 0.912 & 0.983 & 0.996 \\
$2010-2011$ & 0.895 & 0.219 & 0.921 & 0.982 & 0.996 \\
$2012-2013$ & 0.879 & 0.241 & 0.907 & 0.979 & 0.995 \\
$2014-2015$ & 0.865 & 0.257 & 0.890 & 0.976 & 0.994 \\
\hline
\end{tabular}

Panel B: The adjusted-R-squared from the regression based on analysts' forecast values.

\begin{tabular}{llllll}
\hline Period & Mean & STD & Q1 & Median & Q3 \\
\hline $2004-2005$ & 0.944 & 0.132 & 0.954 & 0.984 & 0.996 \\
$2006-2007$ & 0.943 & 0.142 & 0.957 & 0.987 & 0.997 \\
$2008-2009$ & 0.945 & 0.130 & 0.958 & 0.991 & 0.998 \\
$2010-2011$ & 0.939 & 0.148 & 0.952 & 0.987 & 0.996 \\
$2012-2013$ & 0.933 & 0.160 & 0.952 & 0.987 & 0.997 \\
$2014-2015$ & 0.924 & 0.167 & 0.940 & 0.985 & 0.996 \\
\hline
\end{tabular}

Table 5 presents the effect of financial analysts' understanding of firms' accounting matching on their earnings forecast accuracy. The empirical results support my H1. In Table 5, the coefficient $\beta_{1}$ on $A B S_{-} R 2_{\text {Analyst, } q-t}$ is positive and statistically significant $\left(\beta_{1}=0.002, p-\right.$ value $\left.<0.05\right)$, and the coefficient $\lambda_{1}$ on $A B S \_$Coef $f_{\text {Analyst }, q-\mathrm{t}}$ is positive and statistically significant $\left(\lambda_{1}=0.004, p-\right.$ value $<$ 0.01 ), consistent with my prediction that financial analysts who have poor understandings of firms' accounting matching produce earnings forecasts with larger forecast errors. In another word, the results suggest that financial analysts who better understand firms' accounting matching produce more accurate earnings forecasts. 


\section{TABLE 5 \\ THE EFFECT OF FINANCIAL ANALYSTS' UNDERSTANDING OF FIRMS' ACCOUNTING MATCHING ON THEIR EARNINGS FORECASTS ACCURACY}

\begin{tabular}{|c|c|c|c|}
\hline Dependent Variable: & Prediction & $\begin{array}{l}\text { Financial Analysts' } \\
E 1\end{array}$ & $\begin{array}{l}\text { Earnings Forecasts } \\
E 1\end{array}$ \\
\hline Size & & $\begin{array}{l}-0.001 * * * \\
(-6.02)\end{array}$ & $\begin{array}{l}-0.001 * * * \\
(-5.75)\end{array}$ \\
\hline BTM & & $\begin{array}{l}0.004 * * * \\
(4.69)\end{array}$ & $\begin{array}{l}0.004^{* * * *} \\
(4.93)\end{array}$ \\
\hline LEV & & $\begin{array}{l}0.006^{* * * *} \\
(4.68)\end{array}$ & $\begin{array}{l}0.006^{* * * *} \\
(4.62)\end{array}$ \\
\hline Margin & & $\begin{array}{l}-0.003 * * * \\
(-2.67)\end{array}$ & $\begin{array}{l}-0.003 * * * \\
(-2.72)\end{array}$ \\
\hline Litigation & & $\begin{array}{l}-0.000 \\
(-0.09)\end{array}$ & $\begin{array}{l}0.000 \\
(0.03)\end{array}$ \\
\hline HITECH & & $\begin{array}{l}0.001^{* * * *} \\
(3.21)\end{array}$ & $\begin{array}{l}0.001 * * * \\
(3.09)\end{array}$ \\
\hline $\mathrm{R} \& \mathrm{D}$ & & $\begin{array}{l}-0.003 \\
(-1.06)\end{array}$ & $\begin{array}{l}-0.003 \\
(-1.10)\end{array}$ \\
\hline Loss & & $\begin{array}{l}0.002 * * * \\
(4.43)\end{array}$ & $\begin{array}{l}0.002^{* * * *} \\
(4.52)\end{array}$ \\
\hline PPE & & $\begin{array}{l}0.001 \\
(1.08)\end{array}$ & $\begin{array}{l}0.001 \\
(1.12)\end{array}$ \\
\hline Alyst_EXP & & $\begin{array}{l}-0.000 \\
(-0.74)\end{array}$ & $\begin{array}{l}-0.000 \\
(-0.73)\end{array}$ \\
\hline Alyst_FEXP & & $\begin{array}{l}0.000 \\
(0.48)\end{array}$ & $\begin{array}{l}0.000 \\
(0.43)\end{array}$ \\
\hline ABS_R2 & + & $\begin{array}{l}0.002 * * \\
(2.28)\end{array}$ & \\
\hline Actual_R2 & & $\begin{array}{l}-0.001 * \\
(-1.89)\end{array}$ & \\
\hline ABS_Coef & + & & $\begin{array}{l}0.004 * * * \\
(3.13)\end{array}$ \\
\hline Actual_Coef & & & $\begin{array}{l}-0.001 * * \\
(-2.25)\end{array}$ \\
\hline Analyst Fixed Effect & & Yes & Yes \\
\hline Year Fixed Effect & & Yes & Yes \\
\hline No. observations & & 28623 & 28623 \\
\hline Adj. R-squared & & 0.359 & 0.360 \\
\hline
\end{tabular}

This table presents regression results of financial analysts' earnings forecasts error on a list of variables. $* * *, * *$ and $*$ indicate significance at the $0.01,0.05$, and 0.10 levels, respectively. $t$-Statistic are reported in parentheses below coefficients. Standard errors are two-way clustered by firm and year. 
In Table 6, I compare the analysts' earnings forecast error, $E 1_{\text {analyst }, q}$, with the estimated earnings forecast error, $E 2_{\text {estımated, } q}$, and find that $E 1_{\text {analyst }, q}$ is significantly smaller than $E 2_{\text {estımated }, q}$, consistent with $\mathrm{H} 2$ that analyst earnings forecasts are more accurate than the earnings forecasts based on the historical expense-revenue relation.

\section{TABLE 6 \\ COMPARISON OF ANALYST EARNINGS FORECASTS AND THE EARNINGS FORECASTS BASED ON THE HISTORICAL EXPENSE REVENUE RELATION}

\begin{tabular}{llllllll}
\hline \multicolumn{2}{c}{ E1 } & \multicolumn{2}{c}{ E2 } & & & \\
\hline Mean & STD & Mean & STD & $\begin{array}{l}\text { Mean Difference }= \\
\text { Mean (E1-E2) }\end{array}$ & $\begin{array}{l}\text { Standard } \\
\text { Error }\end{array}$ & $\begin{array}{l}\text { Standard } \\
\text { Deviation }\end{array}$ & $t$-statistics \\
\hline 0.003 & 0.006 & 0.006 & 0.022 & $-0.003^{* * *}$ & 0.000 & 0.045 & -30.621 \\
\hline
\end{tabular}

\section{CONCLUSION}

This study explores the linkage between financial analysts' understanding of accounting matching (defined as the recognition of expenses attributable to recognized revenues) and their earnings forecast accuracy.

This study contributes to both of the financial analyst literature and accounting matching literature by showing that better understanding of firms' accounting matching helps financial analysts to determine the components of firms' accounting numbers and thus produce more accurate earnings forecasts, and that analyst earnings forecasts are more accurate than the earnings forecasts based on the historical expenserevenue relation. The findings suggest that better understanding of firms' accounting matching facilitates analysts forecast decision process and reflects analysts' valuable insights into the properties of firms' earnings and their abilities to produce earnings forecasts with greater accuracy, and that since analysts use various information as input to forecast earnings, their forecasts are more accurate than the earnings forecasts that are solely based on the historical expense-revenue relation.

This study focuses on financial analysts' understanding of accounting matching and their earnings forecasts. Future study can also examine financial analysts' understanding of accounting matching and their revenues forecasts.

\section{ACKNOWLEDGEMENTS}

I thank participants at the 2017 University of Texas at Dallas accounting Ph.D. seminar and the 2019 AAA Midwest Region Meeting for their helpful comments and suggestions.

\section{REFERENCES}

Bradshaw, M. (2009). Analyst information processing, financial regulation, and academic research. The Accounting Review, 84(4), 1073-1083.

Bradshaw, M. (2011). Analysts' forecasts: What do we know after decades of work? Working paper, Faculty of Boston College, MA, United States.

Bushman, R.M., Lerman, A., \& Zhang, F. (2015). The Changing Landscape of Accrual Accounting. Journal of Accounting Research, 54(1), 41-78.

Chen, T., \& Martin, X. (2011). Do bank-affiliated analysts benefit from lending relationships? Journal of Accounting Research, 49(3), 633-675.

Core, J., Guay, W., \& Verdi, R., (2008). Is accruals quality a priced risk factor? Journal of Accounting and Economics, 46(1), 2-22. 
Dhaliwal, D.S., Li, O.Z., Tsang, A., \& Yang, Y.G. (2011). Voluntary nonfinancial disclosure and the cost of equity capital: The initiation of corporate social responsibility reporting. The Accounting Review, 86(1), 59-100.

Dichev, I.D., \& Tang, V.W. (2008). Matching and the changing properties of accounting earnings over the last 40 years. The Accounting Review, 83(6), 1425-1460.

Donelson, D.C., Jennings, R., \& McInnis, J. (2011). Changes over time in the revenue-expense relation: Accounting or economics? The Accounting Review, 86(3), 945-974.

He, W., \& Shan, Y. (2016). International evidence on the matching between revenues and expenses. Contemporary Accounting Research, 33(3), 1267-1297.

Johnson, M.E, Kasznik, R., \& Nelson, K.K. (2001). The impact of securities litigation reform on the disclosure of forward-looking information by high technology firms. Journal of Accounting Research, 39(2), 297-327.

LaFond, R., \& Watts, R.L. (2008). The information role of conservative financial statements. The Accounting Review, 83(2), 447-478.

Lee, J. (2011). Measuring reporting conservatism using the Dichev-Tang (2008) model. Working paper, Faculty of School of Accountancy, Singapore Management University, Singapore, July.

Lee, S., Pandit, S., \& Richard, H.W. (2013). Equity method investments and sell-side analysts' information environment. The Accounting Review, 88(6), 2089-2115.

Prakash, R., \& Sinha, N. (2013). Deferred revenues and the matching of revenues and expenses. Contemporary Accounting Research, 30(2), 517-548.

Srivastava, A. (2011). Why has matching declined? Working paper, Faculty of Haskayne School of Business, University of Calgary, Calgary, Alberta, Canada.

Srivastava, A. (2014). Why have measures of earnings quality changed over time? Journal of Accounting and Economics, 57(2-3), 196-217. 